\title{
Influence of the physiological status of bacteria on their transport into permeable sediments
}

\author{
Susanne Heise ${ }^{1, *}$, Giselher Gust ${ }^{2}$ \\ ${ }^{1}$ Department of Biological Oceanography, Baltic Sea Research Institute, Seestrasse 15, 18119 Warnemünde, Germany \\ ${ }^{2}$ Department of Ocean Engineering 1, Technical University Hamburg-Harburg, Lauenbruch Ost 1, 21079 Hamburg, Germany
}

\begin{abstract}
Starving and grown cultures of the heterotrophic, marine isolate FL2 were exposed to a defined flow at a hydrodynamically smooth, sandy sediment-water interface with a partially homogeneous bottom shear stress pattern but localized high advective inflow. Since transport-determining properties like cell size, hydrophobicity, motility and exopolymer production all change during starvation, we compared the distribution of differently nourished cells and microspheres at the surface and in the sediment after $3 \mathrm{~d}$ of exposure. We found different sorting processes between particles and bacteria, and between starving and grown cells, calling into question the transfer of laboratory results from exponentially grown cultures to in situ conditions and generally the substitution of bacteria by particles in transport experiments. While microspheres were distributed according to the advective flow and only weakly retained by interactions with sediment particles, grown bacteria showed a spatially homogeneous distribution over the sediment surface. One suggestion is that active movement renders them independent of advective inflow once they have contact with the sediment. Starved cells, however, accumulated at the surface area of highest advective flow. They excreted exopolymers different from those in exponential phase, and, consequently, formed aggregates of up to $7 \mu \mathrm{m}$ in diameter, which were then retained at the surface due to straining. If this accumulation turns out to be a widespread behaviour of copiotrophic bacteria, possible consequences - both ecological and also regarding pathogenic bacteria in coastal zones - have to be considered.
\end{abstract}

KEY WORDS: Transport into sediment $\cdot$ Starving bacteria $\cdot$ Microspheres $\cdot$ Exopolymers $\cdot$ Straining

\section{INTRODUCTION}

Transport and fate of bacteria in soil has attracted considerable interest due to water-borne diseases that, in the 1970s in the USA, were frequently reported to be caused by sewage pollution of groundwater (Craun 1985). Conceptual and mathematical models for microbial transport in porous media have been developed as a tool not only for risk evaluation but also for understanding the dispersion pattern observed in terrestrial, limnic, riverine and marine porewaters (Corapcioglu \& Haridas 1984, 1985, Taylor \& Jaffé 1990). These authors discussed advective transport and hydrodynamic dispersion, motility of microorganisms and mechanisms responsible for retardation of microbes relative to water

\footnotetext{
- Present address: Department of Ecological Science and Technology, Technical University Hamburg-Harburg, Eissendorfer Strasse 40, 21073 Hamburg, Germany.

E-mail: s.heise@tu-harburg.de
}

movements in the pore space. The mechanisms include processes such as (1) straining, which is filtering of particles, (2) adhesion, (3) interception, and (4) sedimentation. Growth, decay and/or death of bacteria were considered as well. While the models cited above are in good agreement with the observations of terrestrial soil pollution where bacteria are transported while immersed in the fluid in which they thrive, in coastal sediments the situation is different with regard to strength and direction of hydrodynamic forces and properties of bacteria. Here the possible role of pore space as a reservoir for opportunistic pathogens such as Vibrio parahaemolyticus, and for indicator bacteria like Escherichia coli, has been addressed by the bacterial transport studies of Simmann \& Rheinheimer (1975), Venkateswaran et al. (1990), and Davies et al. (1995). At the sediment-water interface, transport of passive particles occurs by advection according to the near-bottom hydrodynamic regime which for permeable sediments extends beneath the sediment-water interface into the 
pore space. In particular, pore pressure gradients that result from microtopography of sedimentological and biological origin set up a powerful physical conveyorbelt for bacterial transport into this pore space (Hüttel \& Gust 1992a, Hüttel et al. 1996). Yet, to the knowledge of the authors, to date no attention has been given to the physiological difference between grown and starving cells as a possible factor affecting bacterial transport and distribution in permeable sediments. Copiotrophic bacteria in marine waters, and sometimes even in coastal areas, are often nutrient limited and have to undergo starvation survival if no plankton bloom provides suitable and available substrates. Bacteria transported in the near-bed zone (benthic boundary layer) can thus be grown cells or starved cells, depending on the carbon supply, exhibiting different features in respect to morphology and physiology, as reviewed extensively in Kjelleberg (1993). Factors like bacteria size (Fontes et al. 1991), hydrophobicity, electrostatic charge of the cell surface and presence of capsules and flagella (Gannon et al. 1991a,b) have been identified as affecting transport and are also subject to change in the case of nutrient deprivation (Kjelleberg 1993).

The purpose of this study was to examine the possibility of different transport patterns and transport rates of starved and grown cells of a copiotrophic bacterium into permeable fine-grained sediments under known hydrodynamic conditions at the interface, to identify any differences between these 2 types of cell and with abiotic passive particles of comparable diameter, to assess to what extent bacteria of different physiological status can be represented or modelled as passive particles, and to point out ensuing ecological consequences.

\section{MATERIALS AND METHODS}

Bacterial strain. The strain FL2 was isolated from the internal fluid of a bivalve (Arctica islandica) from the Baltic Sea. It is a non-spore-forming, Gram-negative $\operatorname{rod}\left(1.0\right.$ to $1.4 \mu \mathrm{m}^{3}$ during exponential phase) that is oxidase-positive and glucose fermenting. Growth on TCBS-Agar, sensitivity against $10 \mu \mathrm{g}$ discs of $0 / 129$ vibriostaticum, lack of growth in less than $5 \mathrm{~g} \mathrm{l}^{-1} \mathrm{NaCl}$, production of arginine dihydrolase, lack of production of lysin-decarboxylase and ornithin-decarboxylase, and the comparison of API 20E-test results with Maugeri et al. (1983) resulted in the tentative identification of FL2 as fish pathogenic Vibrio anguillarum. Under aerobic carbon starvation FL2 survived for $8 w k$, showing a reduction in direct viable cell counts (DVC, according to Kogure et al. 1979) of 2 orders of magnitude over this time interval with increasing cell protein concentration. FL2 was grown in liquid culture with $0.1 \%$ yeast extract, $0.5 \%$ peptone and $1.0 \% \mathrm{NaCl}(\mathrm{pH} 7.6)$. To induce starvation, cultures in exponential phase were centrifuged at $7000 \times g$ for $20 \mathrm{~min}$ and resuspended in artificial marine medium $\left(10 \mathrm{~g} \mathrm{l}^{-1}\right)$ with $\mathrm{pH} 7.6$ and an ionic strength of $0.2 \mathrm{M}$. Cells were starved for at least 2 wk before being used for experiments.

Microspheres. Fluorescent microparticles of 2 different diameters, coated with carboxylate groups (Polysciences), were used for the measurement of passive particle transport. Microspheres with a main axis diameter of $2.2 \mu \mathrm{m}$ were chosen since they are comparable with the cell length of growing FL2 bacteria reaching up to $2.5 \mu \mathrm{m}$. The microsphere volume of $5.6 \mathrm{\mu m}^{3}$ exceeded that of the largest rod formed, exponentially

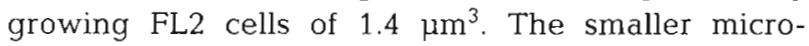
spheres had a diameter of $0.7 \mu \mathrm{m}$, yielding a volume of $0.2 \mu \mathrm{m}^{3}$. This corresponded well with starved, rounded FL2 cells where cell volumes had been observed to decrease beneath $0.2 \mu^{3}$ after $90 \mathrm{~h}$ of starvation (Heise \& Reichardt 1991).

Sediment and medium parameters. The same sandy sediment (grain size: $54 \%$ between 250 and $400 \mu \mathrm{m}$, $84.6 \%$ between 212 and $600 \mu \mathrm{m}$ ) with a pore water content of $20.8 \pm 0.8 \%$ (wt), resulting in a porosity of 0.39 , was used as porous medium in all experiments. Prior to each experiment the sand was mixed with $4 \mathrm{M} \mathrm{NaOH}$ solution and autoclaved to disintegrate attached bacterial cells. It was thoroughly washed afterwards and autoclaved again. The sediment was overlain with artificial seawater which had been autoclaved and filtered to remove all precipitations. An $\mathrm{NaCl}$ solution of $10 \mathrm{~g} \mathrm{l}^{-1}$ was chosen to simulate brackish water conditions; $\mathrm{pH}$ was adjusted to 7.6 using sterile $\mathrm{NaOH}$ solution. Ionic strength of the medium was about $0.2 \mathrm{M}$. The acrylic chamber confining the fluid and sediment core was rinsed with ethanol before addition of sand and medium, thus ensuring initial aseptic conditions.

Experimental procedures. Table 1 contains the nomenclature used in this study.

Table 1. Nomenclature used in this study

\begin{tabular}{|ll|}
\hline$r$ & Radius \\
$\tau$ & Bottom stress \\
$\tau_{d}$ & Depositional stress \\
$u$. & Friction velocity \\
$u_{\cdot c r i}$ & Critical friction velocity \\
$w_{s}$ & Settling velocity \\
$Q$ & Flow rate \\
$J_{v}$ & Advective flux of particles \\
$J_{w}$ & Porewater flow \\
$J_{B}$ & Transport due to Brownian motion \\
$V_{\mathrm{w}}$ & Water flow velocity \\
$\Phi$ & Porosity \\
$D_{B}$ & Diffusion coefficient \\
$D_{1}$ & Motility coefficient \\
$H_{\mathrm{w}}$ & Medium viscosity \\
$d_{\mathrm{n}}$ & Matrix particle diameter \\
$d_{\mathrm{S}}$ & Suspended particle diameter \\
$C$ & Concentration \\
\hline
\end{tabular}


Experimental set up: To evaluate transport pathways and transport rates of cells and particles a defined flow regime both above and in the sediment is required stable, with a stationary pattern of interfacial bottom stress and magnitude and direction of the porewater flow. An acrylic cylindrical chamber (inner diameter. $19 \mathrm{~cm}$; total height: $15 \mathrm{~cm}$ ) which contained $1.4 \mathrm{dm}^{3}$ of sediment, forming a $5 \mathrm{~cm}$ deep layer, and approximately $3 \mathrm{l}$ of artificial seawater was used. The chamber was closed, with a lid, $10 \mathrm{~cm}$ above the sediment. The water was moved by a central, lid-mounted, horizontally rotating disk of $15 \mathrm{~cm}$ diameter with a $3 \mathrm{~cm}$ deep skirt attached at its outer edge. The disk was located $8 \mathrm{~cm}$ above the sediment (Gust 1987). Continuous turning of the disk at $30 \mathrm{rpm}$ created a radial, horizontal pressure gradient with low pressure in the centre and a spatially, nearly homogeneous bottom stress pattern of $\tau=0.09 \mathrm{~N} \mathrm{~m}^{-2}$ at $3<r<7 \mathrm{~cm}$ ( $r$ : radius).

Material (dye, microspheres of 2 different diameters, or bacterial population in either of 2 different physiological conditions, starved or exponentially grown) was added to the supernatant water of each experimental set up after a minimum of $3 \mathrm{~h}$ of stirring at $30 \mathrm{rpm}$. This stirring rate was maintained throughout each experiment, ensuring the same stable flow regime in both the water column and the pore space. Transport of material to and into the sediment was determined either at discrete times, varying between 0.5 and 40 h during the experiment (rhodamine B), or after $3 \mathrm{~d}$, when experiments ended (bacteria, microspheres). The sediment core was newly prepared for each experimental run. Each kind of experimental set up was repeated twice.

Hydrodynamic forces: Stirring the fluid at $30 \mathrm{rpm}$ led to a mean friction velocity $u$. of $0.56 \mathrm{~cm} \mathrm{~s}^{-t}$, with the radial distribution of the friction velocity at the sediment-water interface as shown in Fig. 1. A viscous sublayer of $1000 \mu \mathrm{m}$ thickness was then formed in the fluid region closest to the bed since the roughness Reynolds

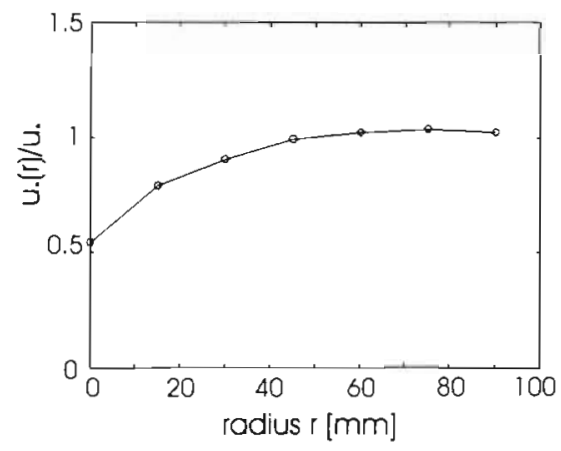

Fig. 1. Radial distribution of skin friction velocity $u_{0}\left[u_{\bullet}(r) / u.\right]$ in the stirring chamber at $30 \mathrm{rpm}$ and without pumping, based on experimental data number Re. was <5. After spin-up, the overlying water body moved in a solid-body rotation with a secondary flow cell transporting fluid downwards at the side walls (outer radial positions). The horizontal pressure gradient established in such axisymmetric flows generates advective porewater flows in permeable sediments. Detailed experimental results of such a flow pattern are presented in Hüttel \& Gust (1992a) and Hüttel et al. (1996), and it has been modelled by Khalili et al. (1997). The magnitude and variance of the bottom stress, the horizontal pressure gradients and porewater exchange rates, as reliably generated in the chamber, resemble those for smooth (Gust \& Müller 1997) and (bio)rough permeable microtopography (Hüttel \& Gust 1992b)

A spatially averaged $u$. of $0.56 \mathrm{~cm} \mathrm{~s}^{-1}$, in conjunction with the settling velocities $w_{\mathrm{s}}$ of the cells and microspheres used, established a flow scenario in which the critical friction velocity $u_{\text {. crit }}$ of the sectiment grains was not reached, yet stayed above the depositional stress $\left(\tau_{d}\right)$ of the suspended particles (cells and microspheres). In such a setting, differences in the rates and spatial pattern of accumulation of the particles (cells and microspheres) will point to the hydrodynamic forces (advection, bottom stress) and particle characteristics which control the dispersion both at the interface and deeper in the sediment. To study the water transport pattern in the sediment, rhodamine $B$ was used as a dye since it does not stain sediment grains. A concentrated solution of rhodamine $\mathrm{B}$ was added to the overlying water, yielding a final concentration of $20.5 \mathrm{mg} \mathrm{l}^{-1}$. At $0.5,1.5,3,5,16$ and $40 \mathrm{~h}$ into the experiment, porewater was sampled, using syringes, from different depths and distances from the centre of the chamber, as shown in Fig. 2 ; the local dye concentrations were then measured photometrically.

Speed of inflow at the edge of the chamber was determined in subsequent experiments by releasing drops of dye at the sediment surface. Movement of the dye front into the sediment with time was monitored visually from the outside, while contimuously stirring the water at $30 \mathrm{rpm}$.

Bacterial transport: For each newly set up experiment, after $3 \mathrm{~h}$ of continuous stirring, a concentrated suspension of either starving or grown bacteria was added to the water, producing an initial bacterial titer of about $10^{6}$ to $10^{7}$ cells $\mathrm{ml}^{-1}$. At constant stirring rate (30 rpm), the suspension was incubated in the chamber for $3 \mathrm{~d}$ at $20^{\circ} \mathrm{C}$. At the end of the experiment, the overlying water was carefully removed, leaving the sediment core and surface intact.

Five $\mathrm{ml}$ syringes with cut tops were used to extract 3 sediment columns of $5 \mathrm{~cm}$ depth at each of 3 different radii $(3,5$, and $7 \mathrm{~cm})$ and 1 column from the centre. From each sediment column, subsamples were taken 

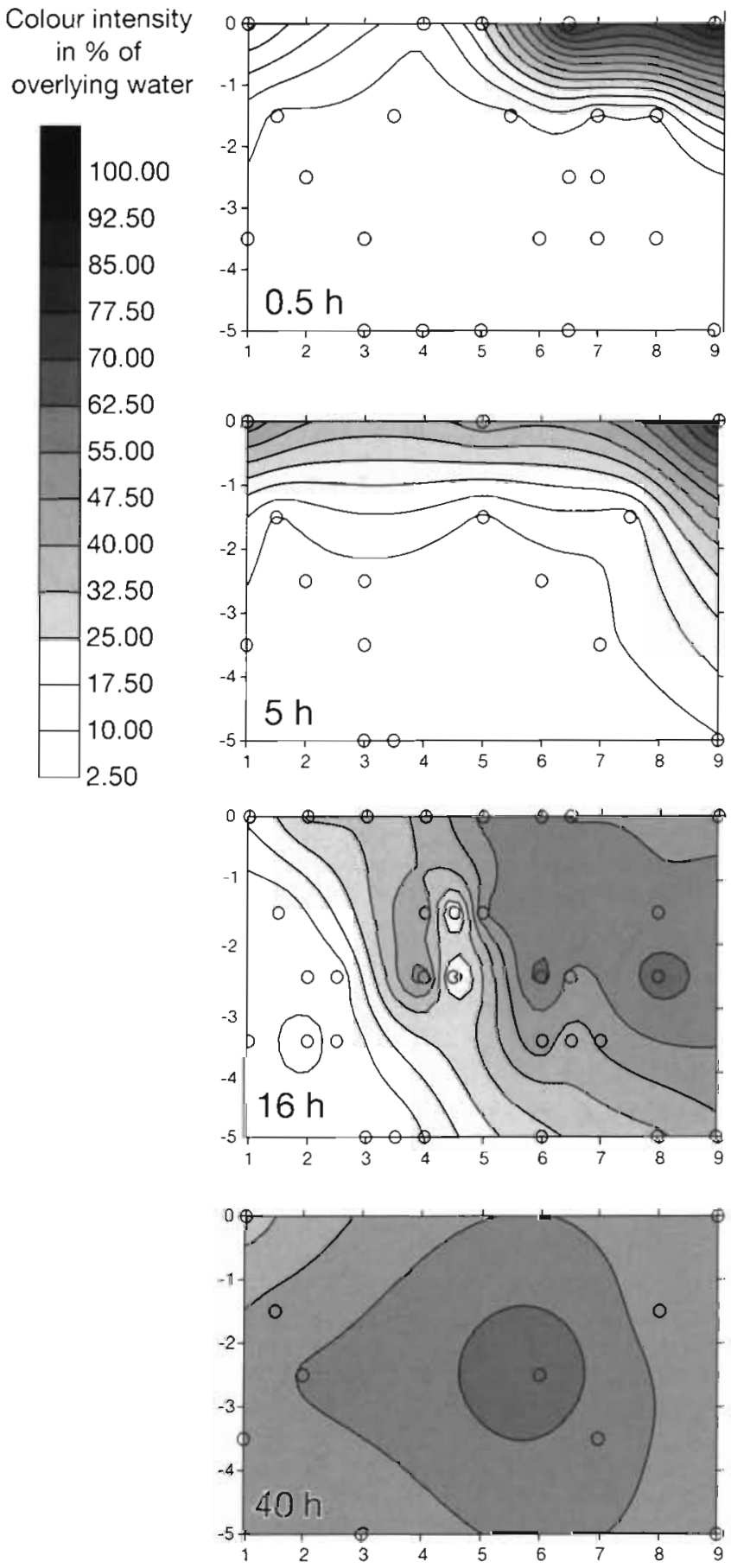

Fig. 2. Distribution of rhodamine $B$ in the sediment beneath the radius 1 to $9 \mathrm{~cm}$ and with depth $(0$ to $-5 \mathrm{~cm})$ at different times after addition to the overlying water. Concentration is given as percentage of the initial water concentration. Gridding was done by kriging to emphasize trends. (0) Sampling points

at 4 different sediment depths (surface: 0 to $0.5 \mathrm{~cm}$; subsurface 1 to $1.5 \mathrm{~cm}$; intermediate: 2 to $3 \mathrm{~cm}$; and bottom layer: 4 to $5 \mathrm{~cm}$ ) and stored at $5^{\circ} \mathrm{C}$ in $4 \%$ formaldehyde until a direct cell count, following the acridine orange method of Zimmermann \& Meyer-Reil (1974), was carried out.

Passive-particle transport pattern in porewater: Concentrated suspensions of fluorescent microspheres of 2.2 and $0.72 \mu \mathrm{m}$ diameter, respectively, were added at the same time to the overlying water after ultrasonification until concentrations of $1.4 \times 10^{6}$ (diameter: $2.2 \mu \mathrm{m}$ ) and $1.11 \times 10^{7}$ (diameter: $0.72 \mu \mathrm{m}$ ) particles $\mathrm{cm}^{-3}$ were reached. The experiment was carried out similarly to those with bacterial cells, except that after $3 \mathrm{~d}$ of stirring as many sediment samples were taken as was possible without disturbing proximate surfaces due to the handling procedure. Former studies had shown difficulties in removing microspheres completely from the sediment, resulting in a high background count for following runs; thus only 1 run with microspheres could be reliably performed with the same sediment that had been used in the experiments with bacterial cells. Therefore a statistical evaluation of the microsphere distribution was decided against in favour of a denser data grid on which concentration isolines could be drawn.

We took 18 sediment samples at the end of the experiment at the centre and randomly at various radial distances. The washed-in spheres were counted at the same 4 depth horizons as the bacterial cells (see above) by fluorescent light microscopy. A total of 6 experimental runs were carried out: 2 for starving bacteria, 2 for exponentially grown bacteria, 1 with dyed fluid, and 1 with a mixture of fluorescent microspheres of 2.2 and $0.72 \mu \mathrm{m}$ in diameter.

The experimental design as a representation of natural sand ecosystems: Hüttel \& Gust (1992a) showed flow pattern around bioroughness to consist of convergence/divergence and pore-space transport zones in permeable sediments. They also identified the ensuing horizontal pressure gradients around bioroughness elements. The mathematical representation of the existing subsurface flows was represented by a potential flow concept with source-sink terms placed at selected positions relative to the roughness by Hüttel et al. (1996) and have also been modelled by other techniques (Khalili et al. 1997).

The experimental set up, with a circular, stirred chamber and a defined subsurface flow pattern, as used in our study and by Hüttel \& Gust (1992b), can be linked to porewater flow around natural bioroughness by comparing the similarities between the pressure distribution over the smooth bottom inside the chamber and the same horizontal advective flow through the pore space of the confined sediment as can be observed for a natural field site with a particular bioroughness. The hydrodynamic adjustments of the stirred chamber thus have to be made according to the pressure gradient, and not the bottom stress, as the 
roughness type may change. For example, Hüttel \& Gust (1992b) determined the horizontal pressure gradient $\nabla p$ of a mound of $1.7 \mathrm{~cm}$ height to be $0.9 \mathrm{~Pa} \mathrm{~cm} \mathrm{~cm}^{-1}$. This is the same pressure gradient established in our experimental setting at a stirring rate of $30 \mathrm{rpm}$. Thus our experimental design is such that the advective flushing rate of porewater fluid is approximately equivalent to a field of similarly high mounds in a natural setting with a homogeneous mound density.

In addition to the link between the chamber experiments and natural ecosystem processes, we had to ensure that in our experimental set up we provided the concise means to identify the 2 different hydrodynamic forces acting at the substrate-fluid interface: the fields of pressure and bottom stress (which are the normal and tangential components at a substrate-fluid interface). In addition, the chosen settings should provide stable and reliable experimental conditions for the transport of fluid, solutes and particles through the pore space. It will be shown below that the microorganisms and particles reached the surface zone of the sediment ( 0 to $0.5 \mathrm{~cm}$ ) through advective flushing since the depositional stress $\tau_{\mathrm{d}}$ was much lower than the shear stress applied.

The accumulation of the larger particles in the outer zones of the cylindrical vessel cannot be explained by centrifugal effects. The radial pressure gradient in the bottom boundary layer of the chamber is given by Euler's equation (in cylindrical coordinates). In this layer the equilibrium between pressure forces and centrifugal forces per unit volume is disturbed and a secondary flow is established which moves towards the centre in logarithmic spirals taking sinking particles along (see, for example, Figs. 5 \& 20 of Denk \& Dürholt 1991).

Analysis: Apart from determination of particle concentration, the bacterial populations required further analysis to distinguish differences between the 2 physiological statuses for subsequent hypothesis testing. The 3 starvation-related factors that could influence the flushing of bacteria into the pore space are the size of bacteria, hydrophobicity and exopolymer production. Of these, size and volume of bacteria were determined by epifluorescence microscopy using a 'New Porton' Grid G12 (GRATICULES Ltd). Hydrophobicity was determined with the BATH-Method (Rosenberg et al. 1980) by measuring the tendency of cells to adhere to hydrocarbons. By determining the optical density after mixing subsamples of a bacterial culture from the recovered probe material with octane, hexadecane and xylol, respectively, and comparing it with the original cell density, a percentage of adherence to the hydrophobic phase was calculated. Exopolymers were extracted from subsamples of the sediment samples by centrifugation at $25000 \times g$ at $4^{\circ} \mathrm{C}$ for $30 \mathrm{~min}$, and pre- cipitated according to Sutherland \& Wilkinson (1971): the supernatant was added to 3 parts of $-80^{\circ} \mathrm{C}$ cold acetone and stored overnight at $0^{\circ} \mathrm{C}$. After centrifugation at $7000 \times g$ for $15 \mathrm{~min}$, the pellet was resuspended in Milli-Q water and dialysed at $0^{\circ} \mathrm{C}$ overnight against 251 distilled water. Carbohydrate and protein contents in the exopolymers were determined by biochemical analysis. Carbohydrate analyses were done according to Dubois et al. (1956); for protein analysis a Bio-RAD Protein Assay that is based on the Bradford-method (Bradford 1976) was used.

In addition to the analysis of extracted exopolymers, carbohydrates and proteins were determined from the substances retained on $5 \mu \mathrm{m}$ polycarbonate filters through which starving and grown cultures had been passed.

\section{RESULTS}

\section{Interfacial and porewater flow regime}

The transport pattern of rhodamine B into the sediment bed revealed a high inflow of water at outer radial positions $r>7 \mathrm{~cm}$. Here, a downward-directed porewater velocity of $2.3 \mathrm{~cm} \mathrm{~h}^{-1}$ was observed in the top $1.5 \mathrm{~cm}$ of the sediment at an interfacial friction velocity of $0.56 \mathrm{~cm} \mathrm{~s}^{-1}$. Below $1.5 \mathrm{~cm}$, porewater speed decreased with increasing depth into the sediment to $0.5 \mathrm{~cm} \mathrm{~h}^{-1}$ due to the diversion of flow paths for constant flow rate $Q$. This pattern corresponds well with observations regarding the porewater flow pattern in a stirred chamber of $30 \mathrm{~cm}$ reported by Hüttel \& Gust (1992a), and also with observations of the pattern through permeable biogenic sediment structures (Hüttel \& Gust 1992 b). These authors recorded a decrease in velocity of downward-moving porewater beneath mounds of $2.5 \mathrm{~cm}$ height from $9.6 \mathrm{~cm} \mathrm{~h}^{-1}$ in a $0.5 \mathrm{~cm}$ thick top layer to $2 \mathrm{~cm} \mathrm{~h}^{-1}$ at $1.3 \mathrm{~cm}$ depth, reaching $0.1 \mathrm{~cm} \mathrm{~h}^{-1}$ at $8 \mathrm{~cm}$ depth; in these experiments, $u$. at the interface between permeable sand and water was $0.7 \mathrm{~cm} \mathrm{~s}^{-1}$. As shown in our contour map of rhodamine concentrations (Fig. 2), the isoline of $47.5 \%$ of the overlying water reached the bottom after $16 \mathrm{~h}$; it possessed a larger horizontal advection component with depth. In the centre of the chamber hardly any inflow was discernible. After $40 \mathrm{~h}$, an almost homogeneous distribution of dye concentration was reached, yet with different flow-through rates $Q$ (radius, depth).

\section{Distribution of bacteria and microspheres}

The mixture of large and small microspheres showed the same distribution pattern in the pore space during 
the first hour as the dye. Concentrations increased at large radii while almost no inflow occurred in the centre (Fig. 3). The shading in Fig. 3A,B, demonstrating relative concentrations of particles (or passive dye as in Fig. 2), is divided into 11 bins. Large microspheres were transported into the sediment in larger numbers, particularly at radii $>6 \mathrm{~cm}$, where high concentrations were flushed to the bottom in $3 \mathrm{~d}$.

In contrast, contour maps of bacteria introduced into the sediment (Fig. 4) revealed an almost homogeneous concentration of grown cells in the surface layer 0 to $0.5 \mathrm{~cm}$ ) after $3 \mathrm{~d}$, while the deeper sediments at $7 \mathrm{~cm}$ distance from the centre showed higher cell counts. Starving bacteria accumulated at the surface of the edge rim of the chamber, with only little transport to deeper layers. Absolute concentrations of grown and starved cells at different sediment depths are shown in Fig. 5.

To estimate the occurrence of cell divisions during the experiment, initial and final cell concentrations of suspended grown and starved bacteria were compared with the range of measured sediment concentrations. For starved cells, the decrease in cell counts was 30 and $13 \%$ in 2.81 of overlying water; this would result in
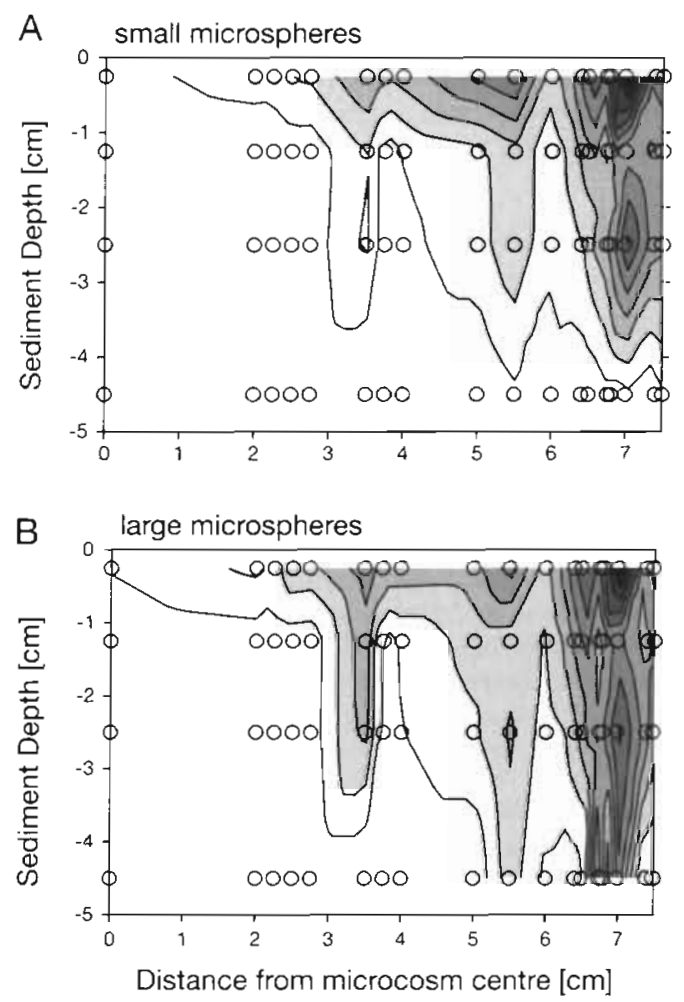

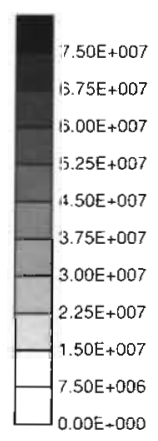

no. of particles $\mathrm{cm}^{-3}$

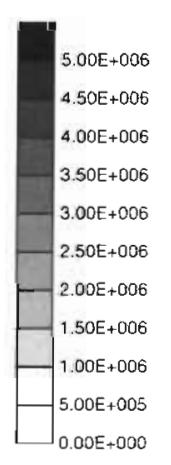

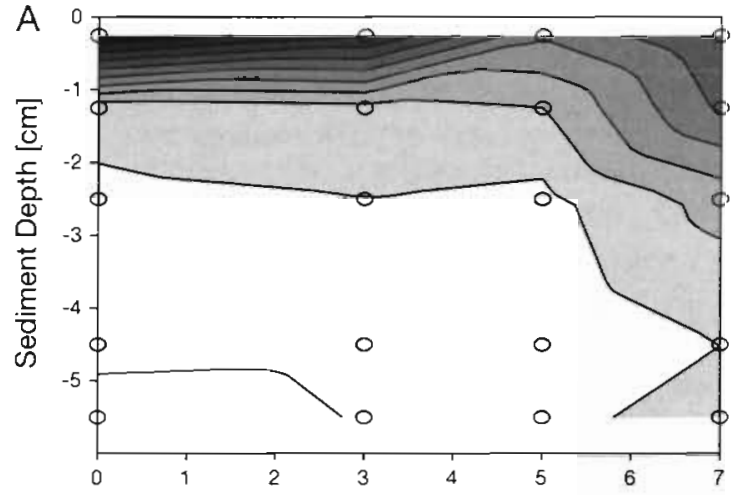

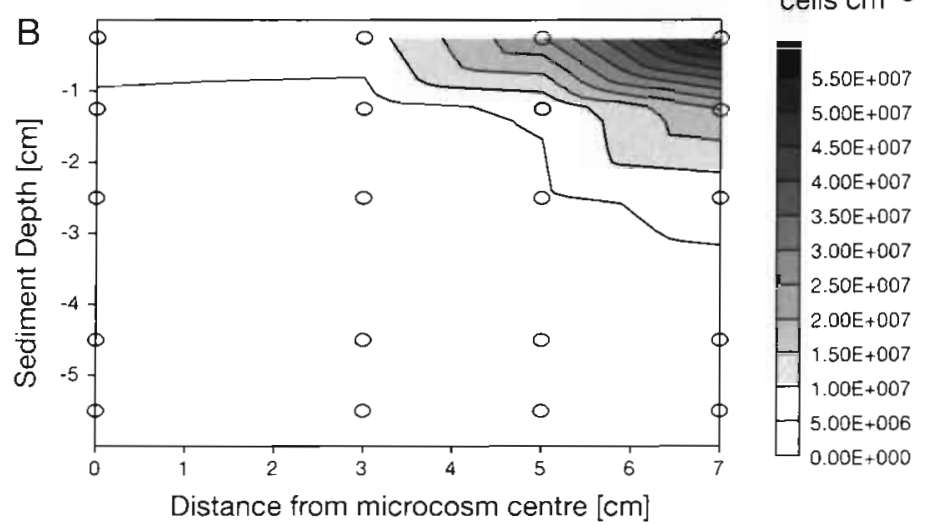

$4.00 \mathrm{E}+007$ $3.60 E+007$ $3.20 \mathrm{E}+007$ $2.80 \mathrm{E}+007$ $2.40 E+007$ $2.00 \mathrm{E}+007$ $1.60 \mathrm{E}+007$ $1.20 \mathrm{E}+007$ $8.00 E+006$ $4.00 E+006$ $0.00 E+000$ no. of

$50 E+007$ OEE+007 $00 E+007$ EE+007 $+007$

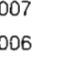

Fig. 4. Distribution of (A) exponentially growm and (B) starved bacteria in the sediment after $3 \mathrm{~d}$ of stirring. Only the data from 1 run are shown. (o) Sampling points. Gridding was done by triangulation versus linear transformation without weighing of data

an average cell count in $1.4 \mathrm{dm}^{3}$ of sediment of $3.2 \times 10^{7}$ and $7 \times 10^{6}$ cells $\mathrm{cm}^{-3}$, assuming that they were evenly distributed. The measured sediment concentrations ranged from $10^{5}$ to $10^{7}$ and $10^{8}$ cells $\mathrm{cm}^{-3}$, respectively, varying strongly and depending on the depth and location of the sample, thus fitting the average estimation well. A net increase in number of starved cells was therefore not assumed. However, it may still be possible that cell divisions and cell lysis made up for each other, which could have been investigated if thymidine incorporation measurements had been done. Increases in cell counts of grown cells in overlying water could be calculated as being due to 3.3 and 3.4 generations within the $72 \mathrm{~h}$ of the experiment, assuming that during the experiment $50 \%$ of the initial cell number was flushed into the sediment. The occurrence of cell divisions showed that enough substrate was available - probably transferred with the inoculum-to the grown cells to prevent a starvation phase after introduction into

Fig. 3. Distribution of microspheres Idiameter: (A) $0.75 \mu \mathrm{m}$; (B) $2.2 \mu \mathrm{m}$ ] in the sediment after $3 \mathrm{~d}$ of stirring. Particles of both kinds were added as a mixture to the overlying water. (o) Sampling points. Gridding for contour mapping was done by triangulation versus linear transformation without weighing of data 

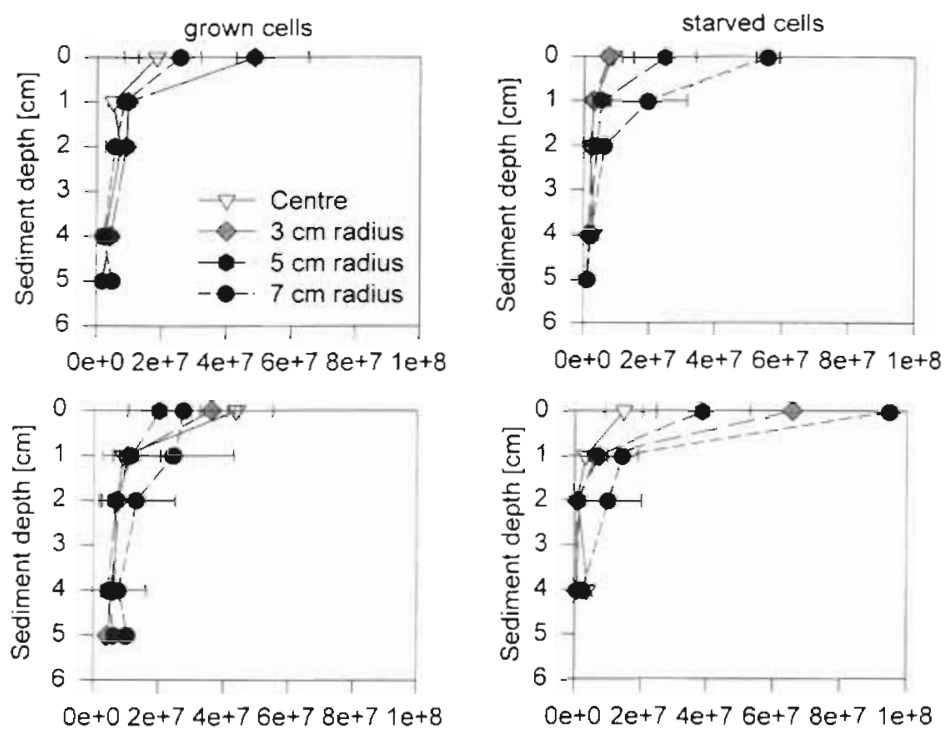

Fig. 5. Distribution of previously grown and starved bacterial cells of FL2 in sediment after $3 \mathrm{~d}$ of incubation in a stirred cylindrical flow chamber. Each value is the average of 3 parallel samples, standard deviations are shown as bars

the mineral medium. However, it can be assumed that the 3 divisions occurred early in the experiment while substrate was available, as cell numbers did not differ very much at the end. The final cell counts were taken in all experiments for calculation of theoretical sediment concentrations from overlying water concentrations. Reduction of microspheres due to the accumulation in the sediment has been noted but not calculated in detail, as no indication of division is needed and its usefulness for checking the number of accumulated cells in the sediment can only be rough due to the highly heterogenous particle distribution in the sediment (as for the starved cells).

Táble 2. Enrichment of bacteria (2 with starving and 2 with grown bacteria: $\mathrm{S} 1, \mathrm{~S} 2, \mathrm{G} 1$, and $\mathrm{G} 2$, respectively) and microspheres (MS) in the sediment surface layer of 4 experiments at $7 \mathrm{~cm}$ radius. The enrichment factor is calculated from the measured particle concentration divided by the theoretical particle concentration (concentration in overlying suspension multiplied by the porosity, 0.39 )

\begin{tabular}{|ccccccc|}
\hline & S1 & S2 & G1 & G2 & $\begin{array}{c}\text { MS } \\
\text { small }\end{array}$ & $\begin{array}{c}\text { MS } \\
\text { large }\end{array}$ \\
\hline $\begin{array}{l}C_{\text {measured }} \\
\left(\times 10^{6} \mathrm{~cm}^{-3}\right)\end{array}$ & 56 & 95 & 47 & 22 & 42 & 2.8 \\
$\begin{array}{l}C_{\text {theoretical }} \\
\left(\times 10^{6} \mathrm{~cm}^{-3}\right) \\
\begin{array}{l}\text { Enrichment } \\
\text { factor }\end{array}\end{array}$ & 15.10 & 16.03 & 7.68 & 8.15 & 9.70 & 5.12 \\
\hline
\end{tabular}

Accumulation in the surface layer is indicated by the ratio of measured to theoretical concentrations in the sediment. The value for the latter is based on the assumption that the available pore space is filled with the same concentration of cells as the overlying water. The theoretical sediment concentration is therefore obtained from multiplying overlying particle concentrations with sediment porosity. Such a concentration would occur in the case of unhindered vertical particle flow through the pore space. Starving cells showed an enrichment ratio of 15 to 16 , grown cells of only 7.7 to 8.2. Microspheres however showed the same or less accumulation than grown cells (Table 2).

The distribution inside the sediment showed a reduction in cell counts with depth in all experiments, for grown and starving cells. In Table 3 , the concentration of bacteria and microspheres in the bottom layer $(4$ to $5 \mathrm{~cm}$ ) is calculated as percentage of the concentration $3 \mathrm{~cm}$ above in the subsurface layer to demonstrate how cells are distributed in deeper sediment layers. Surface concentrations are excluded to avoid any bias through accumulation effects at the water-sediment interface. In experiments with starving cells, the relative concentration of bacteria in the bottom layer at $7 \mathrm{~cm}$ radius is much lower than that of grown bacteria. A still-higher difference exists between the penetration of large and small microspheres.

In the 4 experiments with bacteria ( 2 with starving, 2 with grown bacteria, henceforth called S1, S2, G1, and $G 2$, respectively), the initial bacterial titers were different in the overlying water bodies. Normalization of the cell counts from the water-sediment interface by using the overlying water titer after $3 \mathrm{~d}$ of stirring permitted a statistical analysis of the distributions of starved and grown bacteria in the surface sediment layer $(0$ to $0.5 \mathrm{~cm})$.

For selection of the correct statistical analysis, existence of a normal distribution of absolute surface concentrations ( 3 parallel samples at every radial sampling position from the microcosm centre outwards) was verified for each set of experiments by rankit

Table 3. Particle concentrations in the bottom layer $(4$ to $5 \mathrm{~cm}$ depth) as a percentage of the particle concentration at $1 \mathrm{~cm}$ depth (subsurface) (S1, S2: starving bacteria; G1, G2: grown bacteria; MS: microspheres) at $7 \mathrm{~cm}$ radius

\begin{tabular}{|cccccc|}
\hline S1 & S2 & G1 & G2 & MS small & MS large \\
\hline 12.6 & 17.7 & 32.1 & 24.9 & 20.0 & 113.0 \\
\hline
\end{tabular}


plotting. Subsequently, a t-test was performed for each set of relative data at the different distances between populations S1 and S2, as well as between G1 and G2. This approach was selected since the variances were not significantly different on a $p=1 \%$ level in the $F$-test. The $t$-test showed no significant difference ( $\mathrm{p}>$ $10 \%$ ) between the distance-related data of the 2 parallel experiments; consequently, the data for bacterial concentrations were treated as belonging to 1 population, henceforth called $S$ and $G$, respectively. Subsequently, data from the experiments with starving and grown bacteria were $t$-tested against each other for similar radial location. An increasingly significant difference between concentration data was revealed with distance from the centre outwards, with a highly significant difference between the counts of starving and grown bacteria at $7 \mathrm{~cm}$ radius $(0 \mathrm{~cm}: \mathrm{p}>10 \% ; 3 \mathrm{~cm}$ : $\mathrm{p}>$ $10 \% ; 5 \mathrm{~cm}: 5 \%>\mathrm{p}>2 \% ; 7 \mathrm{~cm}: \mathrm{p}<0.1 \%$ ). Furthermore, a Kolmogorov-Smirnovtest for non-parametric distribution showed a significant difference in the distribution of data sets $\mathrm{S}$ and $\mathrm{G}$ on the $5 \%$ level.

For starved cells, analysis of the bacterial concentrations on the sediment surface revealed an accumulation at the $7 \mathrm{~cm}$ radius where inflow was highest. Bacterial counts increased from $87.5 \%$ of the overlying water in the centre to $568 \%$ at $7 \mathrm{~cm}$ radius. In contrast, grown bacteria were rather evenly distributed throughout the surface and subsurface layer (Fig. 6). Their counts at the surface averaged $167.9 \%$ ( $\mathrm{SD}=66.88$ ) of the water titer. Data were checked for Poisson distribution; the grown bacteria data set showed a random distribution, while the data for starving cells were overdistributed, indicating an unequal distribution at the sediment surface.

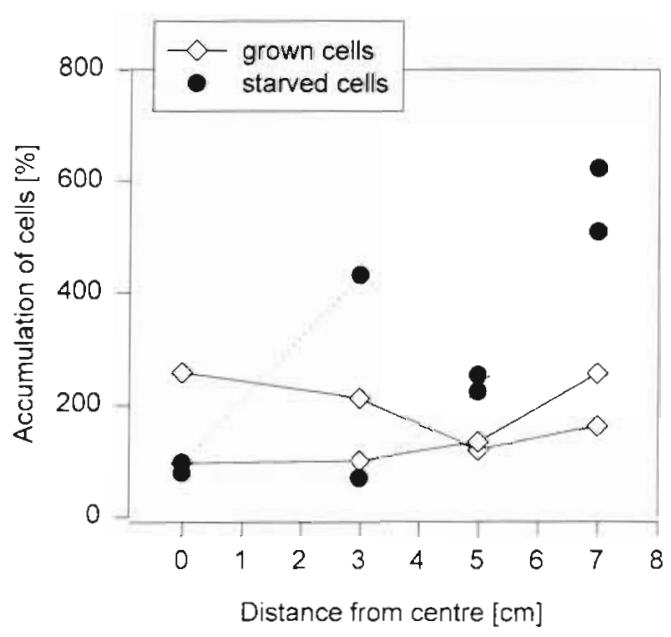

Fig. 6. Bacterial cell counts of starved and grown cells in the sediment surface layer ( 0 to $0.5 \mathrm{~cm}$ depth) in relation to the abundance in overlying water after $3 \mathrm{~d}$ of stirring

\section{Advective flow}

The transport of particles in a permeable medium is mostly due to advective flow of porewater. The advective flux of particles (microorganisms and microspheres) $J_{v}$ is thus due to the strength of the porewater flow $J_{w}$ and is also proportional to the concentration in overlying water $C . J_{w}$ can be calculated by multiplying the average water flow velocity $v_{w}\left(2.3 \mathrm{~cm} \mathrm{~h}^{-1}\right)$ in the pore space with porosity $\Phi(0.39)$ (Tan $\&$ Bond 1995 ) as follows:

$$
J_{\mathrm{v}}=J_{\mathrm{w}} C=v_{\mathrm{w}} \Phi C
$$

The highest possible accumulation of particles would occur if all cells transported by advective flux were retained in the top layer of the sediment during $72 \mathrm{~h}$. Table 4 compares measured particle concentrations in surface and subsurface layers with the largest accumulations theoretically possible $\left(C_{\max }\right)$ at a radius of $7 \mathrm{~cm}$; the transport of the various kinds of particles under similar hydrodynamic settings is different. The accumulation in the surface layer during $72 \mathrm{~h}$ for starved bacteria in both experiments is higher than for grown cells and is largest for microspheres. Large microspheres accumulate less than smaller ones in this zone. In the subsurface layer (1 to $1.5 \mathrm{~cm}$ ) only a small percentage of the theoretical flux is retained. In the top $1.5 \mathrm{~cm}$, the retention rate never exceeds $16 \%$ of particles that enter the pore space at the water-sediment interface. Distributions deeper in the sediment showed a reduction in particle counts with depth in every experiment-with grown cells, starving cells and microspheres (Figs. 3 to 5 ). The associated flow-through rate in the area of highest fluid entry was calculated to be about $116 \mathrm{~cm}^{3} \mathrm{~h}^{-1}$ ( $\left.\mathrm{ca} 0.9 \mathrm{~cm}^{3} \mathrm{~cm}^{-2} \mathrm{~h}^{-1}\right)$; this was the outer rim, the $2.5 \mathrm{~cm}$ edge from the outermost sediment sampling position $(7 \mathrm{~cm})$ to the side wall.

Table 4. Retention of bacteria (S: starved; G: grown) and microspheres at $7 \mathrm{~cm}$ radius in the surface and subsurface layer during the experiment. $C_{\text {max }}$ : theoretically highest possible concentration of particles with complete retention in the sediment over the duration of the experiment $(72 \mathrm{~h})$ with an advective flux $J_{v}$. The percentage of maximal retention is shown for the measured concentrations at the surface $\left(C_{\text {surf }}\right)$ and in the subsurface layer $\left(C_{\text {subsuri }}\right)$

\begin{tabular}{|lcccccc|}
\hline & S1 & S2 & G1 & G2 & $\begin{array}{c}\text { MS } \\
\text { small }\end{array}$ & $\begin{array}{c}\text { MS } \\
\text { large }\end{array}$ \\
\hline$J_{\mathrm{v}}\left(\times 10^{6} \mathrm{~cm}^{-2} \mathrm{~h}^{-1}\right)$ & 9 & 14 & 14 & 6 & 3.8 & 0.35 \\
$C_{\max }\left(\times 10^{6} \mathrm{~cm}^{-3}\right)$ & 650 & 977 & 1008 & 447 & 273 & 25.2 \\
$C_{\text {surf }}\left(\times 10^{6} \mathrm{~cm}^{-3}\right)$ & 56 & 95 & 47 & 22 & 42 & 2.8 \\
$\%$ of max. retention & 8.5 & 9.7 & 4.7 & 4.2 & 15.1 & 11.0 \\
$C_{\text {subsurl }}\left(\times 10^{6} \mathrm{~cm}^{-3}\right)$ & 19 & 15 & 25 & 8.6 & 22 & 1.7 \\
$\%$ of max. retention & 2.9 & 1.5 & 2.5 & 1.9 & 7.9 & 6.7 \\
\hline
\end{tabular}




\section{Brownian diffusion}

An additional process transporting solutes and particles in water is molecular diffusion. Transport of bacterial cells in porous media, both impermeable and permeable, due to Brownian motion $J_{\mathrm{B}}$ is described by Fick's first law:

$$
J_{\mathrm{B}}=-D_{\mathrm{B}} \Phi \nabla C
$$

where $D_{\mathrm{B}}$ is the diffusion coefficient in a porous medium, $\Phi$ the porosity and $\nabla C$ the concentration gradient (Corapcioglu \& Haridas 1985). $D_{\mathrm{B}}$ can be calculated using the Stokes-Einstein equation:

$$
D_{\mathrm{B}}=k_{\mathrm{B}} T\left(3 \pi \mu_{\mathrm{w}} d\right)^{-1}
$$

where $k_{\mathrm{B}}$ is the Boltzmann constant, $1.3806 \times 10^{-23} \mathrm{~J} \mathrm{~K}^{-1}$, and $T$ the absolute temperature, which was $291 \mathrm{~K}$ in our experiments. $\mu_{w}$ is the medium viscosity $\left(1 \times 10^{-3} \mathrm{Ns}\right.$ $\mathrm{m}^{-2}$ ) and $d$ the diameter of the particles (bacteria or microspheres). Starving FL2 cells round off and volume decreases within $8 \mathrm{wk}$ from 1.0 to below $0.1 \mu^{3}$ (Heise 1995). At the beginning of the stirring experiments median cell volumes varied between 0.88 and $1.04 \mu^{3}$ for previously grown bacteria, and between 0.52 and $0.68 \mu^{3}$ for starved bacteria in the pore space of sediments. The mass flux of bacteria-sized particles due to Brownian motion is small; less than 200 cells are transported per $\mathrm{cm}^{2}$ per hour (Table 5). Since the transport is non-directional, it does not contribute measurably to the inflow of bacteria into permeable sediment.

\section{Hydrophobicity}

Santos et al. (1990) defined a change in culture turbidity of more than $50 \%$ in adsorbance as an indication of strong hydrophobicity, 20 to $50 \%$ as moderate, and less than $20 \%$ as not hydrophobic. According to these criteria, exponentially growing cells showed a strong hydrophobicity which decreased with ongoing starvation until no hydrophobicity could be detected after 240 h of starvation (Table 6).

Table 5. Diameter of cells and microspheres in different experiments enabling the calculation of diffusion coefficient

$D_{\mathrm{B}}$ and the flux of particles $J_{\mathrm{B}}$ due to Brownian motion

\begin{tabular}{|lccc|}
\hline Expt & $\begin{array}{c}\text { Cell diameter } \\
(\mu \mathrm{m})\end{array}$ & $\begin{array}{c}D_{\mathrm{B}} \\
\left(\mathrm{cm}^{2} \mathrm{~s}^{-1}\right)\end{array}$ & $\begin{array}{c}J_{\mathrm{B}} \\
\left(\mathrm{cm}^{-2} \mathrm{~h}^{-1}\right)\end{array}$ \\
\hline $\mathrm{G} 1$ & $0.88-1.04$ & $4.84 \times 10^{-9}-4.12 \times 10^{-9}$ & $106-90$ \\
$\mathrm{G} 2$ & $0.88-1.04$ & $4.84 \times 10^{-9}-4.12 \times 10^{-9}$ & $36-31$ \\
S1 & $0.52-0.68$ & $8.23 \times 10^{-9}-6.23 \times 10^{-9}$ & $117-9$ \\
S2 & $0.52-0.68$ & $8.23 \times 10^{-9}-6.23 \times 10^{-9}$ & $206-156$ \\
MS small & 0.72 & $5.92 \times 10^{-9}$ & 35 \\
MS large & 2.2 & $1.94 \times 10^{-9}$ & 1 \\
& & & \\
\hline
\end{tabular}

Table 6 . Hydrophobicity as percentage of adherence to different hydrocarbons for growing cells (from exponential to stationary growth; optical density $\left[O D_{400}\right.$ ] from 0.124 to 0.597 ) and

\begin{tabular}{|c|c|c|c|c|}
\hline Sample & n-hexadecane & n-octane & $p-x y l o l$ & Average \\
\hline \multicolumn{5}{|c|}{ Original $\mathrm{OD}_{400}$ of growing culture } \\
\hline 0.124 & 56.9 & 74.5 & 83.1 & 71.5 \\
\hline 0.31 & 45.7 & 66.1 & 75.1 & 62.3 \\
\hline 0.392 & 15.0 & 68.3 & 70.0 & 51.1 \\
\hline 0.597 & 27.4 & 50.3 & 66.9 & 48.2 \\
\hline \multicolumn{5}{|c|}{ Time starved (h) } \\
\hline 5 & 22.0 & 42.1 & 73.3 & 45.8 \\
\hline 46 & 11.4 & 45.8 & 33.7 & 30.3 \\
\hline 240 & $<1$ & 34.9 & 9.1 & $<15.0$ \\
\hline
\end{tabular}
for cells that were starved for different times $(5,46$ and $240 \mathrm{~h})$

\section{Exopolymer production and aggregates}

For biochemical analysis of aggregates, starving (5 wk) and grown cultures with similar biomass $10.00815 \mathrm{mg} \mathrm{C} \mathrm{cm}^{-3}$ in grown cultures and $0.00977 \mathrm{mg}$ $\mathrm{C} \mathrm{cm}^{-3}$ in starving cultures, calculated from the biovolumes using a factor of 0.22 , according to Borsheim et al. 1990) were used to determine protein to carbohydrate ratios ( $\mathrm{P} / \mathrm{C}$ ratios) in total, in extracted exopolymers and in cultures filtrated on a polycarbonate filter with a pore size of $5 \mu \mathrm{m}$.

$\mathrm{P} / \mathrm{C}$ ratios in extracted exopolymers were lowest in growing cultures, decreasing from 0.5 to 0.1 during exponential phase due to extended production of carbohydrates. The $\mathrm{P} / \mathrm{C}$ ratio in exopolymers of starving cultures rose from 0.1 to 0.7 after the amount of proteinaceous compound increased (see also Heise 1995). Material of starved cultures that was retained on $5 \mu \mathrm{m}$ polycarbonate filters revealed a concentration of protein 2 times higher than that of polysaccharide, while this ratio was 3.2 before filtration. With grown cells, a $\mathrm{P} / \mathrm{C}$ ratio of 1.8 in unfiltered samples and of 0.7 on filters was obtained. In the starved cell suspension, a higher fraction of the whole protein amount was retainable on a $5 \mu \mathrm{m}$ filter than in growing cultures (Table 7). This result is in accordance with observa-

Table 7. Protein to carbohydrate $(\mathrm{P} / \mathrm{C})$ ratios in starvation (starved for $5 \mathrm{wk}$ ) and grown cultures of FL2, in cultures filtered on filters with $5 \mu \mathrm{m}$ pore size and in extracted exopolymers. Extraction was made during either a starvation period of $50 \mathrm{~h}$ or the growth phase $\left(\mathrm{OD}_{400}=0.03-0.7\right)$

\begin{tabular}{|lcc|}
\hline & Starvation culture & Grown culture \\
\hline Suspension & 3.2 & 1.8 \\
Filtered on $5 \mu \mathrm{m}$ filters & 2.2 & 0.7 \\
Extracted exopolymers & $0.1-0.7$ & $0.5-0.1$ \\
\hline
\end{tabular}


tions that have been made using light microscopy. Staining of starving and growing cultures with methylene blue revealed a high abundance of aggregates with an average diameter of $7 \mu \mathrm{m}$ in starving cultures, while growing cells appeared separated and equally distributed under the microscope.

\section{DISCUSSION}

The results suggest definite differences in porespace transport of microspheres and bacteria. The latter also differed depending on whether they were growing or starved. Microspheres are transported to and introduced into the sediment according to the flow pattern, which enters the pore space advectively at the outer radial positions $(r>6 \mathrm{~cm})$. While this also holds for starving bacteria, they are more strongly retained in the surface layer. In contrast, grown cells do not follow the advective-flow pattern. They are almost evenly distributed in the surface layer, but are transported within the sediment more strongly than starving bacteria. Effects from diffusion through the viscous sublayer associated with the nearly homogeneous shear stress distribution (see Fig. 1) are possible but could not be determined in our experiments.

In a first assessment we discuss to what extent differences in Brownian motion, straining, sedimentation, interception or adhesion may have contributed to, and whether physiological status of cells can be held responsible for, the different distributions observed.

An obvious difference between starving and growing bacteria is-next to the cell size - the formation of cocci under nutrient limitation. The results of Jang et al. (1983) indicate that a larger, rod-shaped organism is retained more strongly than a small, spherical organism. Although we cannot exclude that cell morphology may have an influence on transport, there has been little evidence in literature up to now indicating that the shape of cells, rather than cell size, is an important parameter (e.g. Fontes et al. 1991, Gannon et al. 1991a) In our experiments, however, with a theoretically stronger retention of rod-shaped organisms a different pattern would have been expected, resembling the distribution of starved bacteria.

Brownian diffusion also had only a small effect on particle transport in permeable sediments, compared to advective flux. In the latter case, a theoretical mass transfer of $10^{5}$ to $10^{7}$ particles $\mathrm{cm}^{-2} \mathrm{~h}^{-1}$ was given, in contrast to $10^{2}$ when only diffusion is considered (see Tables $4 \& 5$ ).

Nevertheless, transport of microspheres and bacteria in sandy sediments with a grain size $d_{50}$ between 250 to $400 \mu \mathrm{m}$ was reduced compared to the advective porewater flux of rhodamine $\mathrm{B}$. While addition of rhodamine $B$ led to an almost homogeneous distribution of dye concentration throughout the sediment within $40 \mathrm{~h}$, microspheres added to the fluid phase accumulated beneath areas of highest water inflow determined from the $3 \mathrm{~d}$ experiments. Small counts are found closer towards the centre. Grown bacteria were concentrated in surface (0 to $0.5 \mathrm{~cm}$ ) and subsurface (1 to $1.5 \mathrm{~cm}$ ) layers, with spatially homogeneous surface concentrations. In contrast, starved bacteria accumulated mostly at the surface in the area of highest advective inflow.

Straining describes the retardation of particles by means of filtration, with the ratio of matrix particle diameter $d_{\mathrm{m}}$ to suspended particle diameter $d_{\mathrm{s}}$ being an important variable. According to laboratory data on particle capture (Sakthivadivel 1969) no particles can be transported into a porous medium if the ratio $d_{m} / d_{s}$ is less than 10. In such cases 'cake filtration' occurs, i.e. suspended particles accumulate at the surface of the medium. In our experiments, smaller microspheres were retarded more severely than large ones and small starved bacteria more severely than grown ones. The range of values for $d_{\mathrm{m}} / d_{\mathrm{s}}$ obtained in our experiment, with $d_{\mathrm{m}}=240$ to $400 \mu \mathrm{m}$ and $d_{\mathrm{s}}=2.2 \mu \mathrm{m}$, was 110 to 180. Pore sizes in the sand medium were thus too large to restrain single bacterial cells or microspheres. Gravitational sedimentation also cannot explain the accumulation rates. Sedimentation occurs when particles with a density higher than the medium deviate from streamlines, collide and settle on large particles or in niches. Gravitational settling was negligible in our experiments because microspheres and bacteria had nearly the same density as water, ranging between 1.0 and $1.1 \mathrm{~g} \mathrm{~cm}^{-3}$ (e.g. Smith et al. 1985, Characklis 1990).

Interception describes the retardation of suspended particles by their collision with sediment particles. Yao et al. (1971) have shown that only relatively large particles with a diameter of more than $5 \mu \mathrm{m}$ are affected by this process, while most bacteria and viruses are not influenced (Tan \& Bond 1995).

Thus, adhesion processes may be responsible for the retention of microspheres and starved and grown bacterial cells inside the sediment. Reversible adhesion of particles to surfaces is controlled by Van der Waals forces and electrostatic interactions; stronger adhesion is due to polymer bridging (Neu \& Marshall 1990). Van der Waals forces are usually attractive, while electrostatic interactions are repulsive due to the negative charge of surfaces in marine waters. Effects of both forces depend on the distance between surfaces and the ionic strength of the medium due to the formation of double layers. The initial steps of adhesion have been described by the DLVO theory, which relates the Gibbs energy of interaction between particles to their relative distance (Van Loosdrecht et al. 1990c). At intermediate ionic strength, as in our experiments, repulsive forces are quite low. As a result, strong Van der 
Waals forces and high thermal energy can enable bacteria with a negative surface charge to adhere to surfaces (Van Loosdrecht et al. 1990b). Microspheres that are coated with carboxylate groups also tend to be negatively charged at $\mathrm{pH}>7$, and can therefore adhere to sediment particles.

By connecting hydrophobic interactions with Van der Waals forces, Van Loosdrecht et al. (1990b) related experimental data of bacterial adhesion to different surfaces in terms of the DLVO theory. They concluded that hydrophobicity, alone (polystyrene) or in combination with low surface charge (glass), is mainly responsible for adhesion. BATH tests carried out with 3 different hydrocarbons, however, showed that hydrophobicity of cells was strong in the early exponential phase and decreased during the growth cycle. Hydrophobicity even declined further with ongoing starvation, when cells could be called moderately hydrophobic - using the definition proposed by Santos et al. (1990). Earlier experiments with FL2, in which glass slides were exposed to a starving culture, showed a decreasing tendency for adhesion with length of starvation: the number of cells that adhered per hour decreased by $98 \%$ from the onset of starvation to $40 \mathrm{~h}$ in organic-carbon-free medium (Heise 1995).

Microspheres coated with negatively charged carboxylate groups will show electrostatic interaction at medium ionic strength, as their hydrophilic character will prevent Van der Waals forces and therefore strong binding. The stronger retardation of small microspheres can be explained by a chromatography effect: larger cells travel faster because they cannot diffuse into as many pores as smaller particles. Weak interactions probably account for high accumulation of microspheres in the surface layer.

The fact that neither cell size nor hydrophobicity nor adhesion can explain the high concentration of starved cells at the sediment surface points to the involvement of extracellular polymers, which are known to be important factors in irreversible adhesion and desorption of cells (Neu \& Marshall 1991, Neu 1992). On surfaces, adsorbed polymers can influence Van der Waals forces and electrostatic interactions. When covering both surfaces, they might produce steric hinderance (Van Loosdrecht et al. 1990a,b). Not only the constitution, but also the configuration and conformation play an important role in adsorption processes. Consequently, prediction of the effects of polymers on adhesion cannot be made on the basis of pure chemical analysis alone (Neu \& Marshall 1990). The fact that they were able to be extracted from cultures by high-speed centrifugation points to rather loosely linked polymers, the production of which increases with length of starvation. They formed the matrix of aggregates that was microscopically visible.
The filtration of the starvation culture suspension on filters with a pore size of $5 \mu \mathrm{m}$ resulted in the retardation of material with a high $\mathrm{P} / \mathrm{C}$ ratio; this is in accord with the increased protein content of extracted exopolymeric substance of starved FL2 cultures (Table 7). For aggregates of this size, straining becomes increasingly important, since clagging of pores depends on the $d_{\mathrm{m}} / d_{\mathrm{s}}$ ratio, leading to cake filtration below a ratio of 10. This process can explain the strong interfacial accumulation of starved cells of FL2 in the area of highest water flow into the sediment.

Extrapolating our observations to the field suggests that sediment areas covered with aggregates consisting of mucous and starved cells enable bacteria to filter organics out of water that is forced down into the sediment at protruding structures such as mounds and tubes (Hüttel \& Gust 1992b). Thus an even more efficient nutrient capture than in floating particles, as described by Logan \& Hunt (1988), or in biofilms on flat, unpercolated surfaces can be realized.

Grown cells were rather evenly distributed at the sediment surface, which means their distribution did not depend on the inflow regime or was not limited to it. An explanation may be found in the motility of FL2 during exponential growth which has been observed to be lost during starvation. This effect of substrate limitation has also previously been observed for another Vibrio sp. by Malmcrona-Friberg et al. (1990), and is probably a consequence of an energy requirement of small cells that is too high should Brownian motion be overcome (Mitchell 1991). In experiments with grown and thus motile bacteria, the absence of substrate gradients probably prevented chemotaxis. Random tumbling, however, can be described by a motility coefficient $D_{\mathrm{t}}$ which has been calculated by Characklis (1990) to be on the order of $10^{-9} \mathrm{~m}^{-2} \mathrm{~s}^{-1}, 4$ orders of magnitude higher than the diffusion coefficients. Even by random movement it is possible that grown bacteria which came in contact with the sediment reached deeper layers of the porous medium before entering the starvation state.

In comparing the surficial and subsurface pattern and flux intensities, it appears that bacterial transport to and into sediment strongly depends on the kind and physiological state of the microorganism and is different from transport of passive particles (see Table 8). Therefore a substitution of bacteria by artificial parti-

Table 8. Suggested sorting processes for interfacial and porespace transport based on presented data
Microspheres large Microspheres small Starved bacteria Grown bacteria
Gel permeation, passive, discrete

Passive, aggregated, straining Active, dispersed, motile 
cles in experiments has to be carefully considered. It should be stressed, though, that the survival mechanisms of microorganisms are diverse. For example, studies from Bitton et al. (1974) on Klebsiella sp. showed a contrasting behaviour, with exopolymer production starting at the onset of growth, which may explain the much higher subsurface transport of starving cells observed by those authors. In addition, Harvey et al. (1989) described a diverse bacterial population that travelled much faster through sandy aquifer sediments than carboxylated microspheres.

The 'strategy' of FL2 that has been discussed in this paper shows one possible response to carbon limitation, the ecological consequence of which would be the concentration of bacterial biomass on top of permeable sediments, where it would be grazed upon by surface deposit feeders. Furthermore, accumulation of starved bacteria at the sediment surface is of special human interest where opportunistic pathogens are concerned. They are mostly copiotrophs (Poindexter 1981) growing best with a carbon supply of more than $2 \mathrm{mg} \mathrm{l}^{-1}$ and therefore probably are in a state of starvation survival in oligotrophic marine waters. Settling firmly in the form of aggregates at the sediment surface rather than being introduced deep into the sediment would result in easy resuspension and reintroduction into the water column. Further studies should reveal whether it is the rule rather than the exception for starving bacteria to accumulate on top of the sediment.

Acknowledgements. We thank Lutz Viehring for technical assistance, Volker Müller for obtaining the data that lead to Fig. 1, and Susanne Gatti, Andrea Höfle and Jana Schreckenbach for counting bacteria. S.H. was funded by the GKSSTUHH Cooperative Programme under contract no. 09476 during this research.

\section{LITERATURE CITED}

Bitton G, Lahav N, Henis Y (1974) Movement and retention of Klebsiella aerogenes in soil columns. Plant Soil 40 $373-380$

Børsheim KY, Bratbak G, Heldal M (1990) Enumeration and biomass estimation of planktonic bacteria and viruses by transmission electron microscopy. Appl Environ Microbiol $56: 352-356$

Bradford $M$ (1976) $A$ rapid and sensitive method for the quantitation of microgram quantities of protein utilizing the principle of protein-dye binding. Anal Biochem 72: $248-254$

Characklis WG (1990) Biofilm processes. In: Characklis WG, Marshall KC (eds) Biofilms. Wiley-Interscience, New York, p 195-231

Corapcioglu MY, Haridas A (1984) Transport and fate of microorganisms in porous media: a theoretical investigation. J Hydrol 72:146-169

Corapcioglu MY, Haridas A (1985) Microbial transport in soils and groundwater: a numerical model. Adv Water Resour $8: 188-200$
Craun GF (1985) A summary of waterborne illness transmitted through contaminated groundwater. J Environ Heaith 48:122-127

Davies CM, Long JAH, Donald M, Ashbolt NJ (1995) Survival of fecal microorganisms in marine and freshwater sediments. Appl Environ Microbiol 61:1888-1896

Denk V, Dürholt A (1991) Experimental investigations of the unsteady rotating flow field in a cylindrical vessel. Exp Fluids 12:97-105

Dubois M, Gilles KA, Hamilton JK, Rebers PA, Smith F (1956) Colorimetric method for determination of sugars and related substances. Anal Chem 28:350-356

Fontes DE, Mills AL, Hornberger GM, Herman IS (1991) Physical and chemical tactors influencing transport of microorganisms through porous media. Appl Environ Microbiol 57:473-481

Gannon JT, Manilal VB, Alexander M (1991a) Relationship between cell surfaces properties and transport of bacteria through soil. Appl Environ Microbiol 57:190-193

Gannon JT, Tan Y, Baveye P, Alexander M (1991b) Effect of sodium chloride on transport of bacteria in a saturated aquifer material. Appl Environ Microbiol 57:2497-2501

Gust G (1987) Verfahren und Vorrichtung zum Erzeugen von definierten Bodenschubspannungen. Deutsches Patentamt, München, Patent No. 3717969:1-51

Gust G, Müller V (1997) Interfacial hydrodynamics and entrainment functions of currently used erosion devices. In: Burt N, Parker R, Watts J (eds) Cohesive sediments, 4th Nearshore and Estuarine Cohesive Sediment Transport Conference INTERCOH'94. John Wiley and Sons, New York, p 149-174

Harvey RW, George LH, Smith RL, LeBlanc DR (1989) Transport of microspheres and indigenous bacteria through a sandy aquifer: results of natural- and forced-gradient tracer experiments. Environ Sci Technol 23:51-56

Heise S (1995) Der Einfluß von Umweltfaktoren auf die Bildung von exopolymerer Substanz (EP) durch ein marines Bakterium. Berichte aus dem Institut für Meereskunde, Kiel, No. 269

Heise S, Reichardt W (1991) Anaerobic starvation survival of marine bacteria. Kiel Meeresforsch Sonderh 8:97-101

Hüttel M. Gust G (1992a) Impact of bioroughness on interfacial solute exchange in permeable sediments. Mar Ecol Prog Ser 89:253-267

Hüttel M. Gust G (1992b) Solute release mechanisms from confined sediment cores in stirred benthic chambers and flume flows. Mar Ecol Prog Ser 82:187-197

Hüttel M, Ziebis W, Forster S (1996) Flow-induced uptake of particulate matter in permeable sediments. Limnol Oceanogr 41:309-322

Jang LK, Chang PW, Findley JE, Yen TF (1983) Selection of bacteria with favorable transport properties through porous rock for the application of microbial-enhanced oil recovery. Appl Environ Microbiol 46:1066-1072

Khalili A, Basu AJ, Hüttel M (1997) A non-Darcy model for recirculating flow through a fluid-sediment interface in a cylindrical container. Acta Mech 123:75-87

Kjelleberg S (1993) Starvation in bacteria. Plenum Press, New York

Kogure K, Simidu U, Taga N (1979) A tentative direct microscopic method for counting living marine bacteria. Can J Microbiol 25:415-420

Logan BE, Hunt JR (1988) Bioflocculation as a microbial response to substrate limitations. Biotechnol Bioeng 31 : 91-101

Malmcrona-Friberg K, Goodman A, Kjelleberg S (1990) Chemotactic responses of marine Vibrio sp. strain S14 
(CCUG 15956) to low-molecular-weight substances under starvation and recovery conditions. Appl Environ Microbiol 56:3699-3704

Maugeri TL, Crisafi E. Genovese L, Scoglio ME (1983) Identification of Vibrio anguillarum with the API-20E system. Microbiologica 1:73-79

Mitchell JG (1991) The influence of cell size on marine bacterial motility and energetics. Microb Ecol 22:227-238

Neu TR (1992) Microbial 'footprints' and the general ability of microorganisms to label interfaces. Can J Microbiol 38: $1005-1008$

Neu TR, Marshall KC (1990) Bacterial polymers: physicochemical aspects of their interactions at interfaces. Biomat Appl 5: 1.07-133

Neu TR, Marshall KC (1.991) Microbial 'footprints'-a new approach to adhesive polymers. Biofouling 3:101-112

Poindexter JS (1981) Oligotrophy. Fast and famine existence. In: Alexander $M$ (ed) Advances in microbial ecology, Vol 5. Plenum Press, New York, p 63-89

Rosenberg $M$, Gutnick D, Rosenberg E (1980) Adherence of bacteria to hydrocarbons: a simple method for measuring cell-surface hydrophobicity. FEMS Microbiol Lett 9:29-33

Sakthivadivel R (1969) Clogging of a granular porous medium by sediment. Rep HEL 15-7. Hydraul Eng Lab, Univ of California, Berkeley

Santos Y, Bandin I, Nieto TP, Bruno DW, Ellis AE, Toranzo AE (1990) Comparison of the cell surface hydrophobicity of bacterial fish pathogens by different procedures. In: Perkins FO, Cheng TC (eds) Pathology in marine science. Academic Press, San Diego, CA, p 101-115

Simmann J, Rheinheimer G (1975) Untersuchungen über die Ausbreitung und Vermehrung von $E$. coli in Schlick-

Editorial responsibility: Otto Kinne (Editor).

Oldendorf/Luhe, Germany sedimenten von Küstengewässern. Kiel Meeresforsch 31 95-106

Smith MS, Thomas GGW, White RE, Ritonga D (1985) Transport of Escherichia coli through intact and disturbed soil columns. J Environ Qual 14:87-91

Sutherland JW, Wilkinson JF (1971) Chemical extraction of microbial cells. Methods Microbiol 5B:359-371

Tan Y, Bond WJ (1995) Modeling subsurface transport of microorganisms. In: Singh VP (ed) Environmental hydrology. Kluwer Academic Publishers, p 321-355

Taylor SW, Jaffé PR (1990) Substrate and biomass transport in a porous medium. Water Resour Res 26:2181-2194

Van Loosdrecht MCM, Lyklema J, Norde W, van Zehnder AJB (1990a) Influence of interfaces on microbial activity Microbiol Rev 54:75-87

Van Loosdrecht MCM, Norde W, Lyklema J, van Zehnder AJB (1990b) Hydrophobic and electrostatic parameters in bacterial adhesion. Aquat Sci 52:103-114

Van Loosdrecht MCM, Lyklema J, Norde W, van Zehnder AJB (1990c) Bacterial adhesion: a physical chemical approach. Microb Ecol 17;1-1.5

Venkateswaran K. Kilyukia C, Nakanishi K, Nakano H, Matsuda $O$, Hashimoto $H(1990)$ The role of sinking particles in the overwintering process of Vibrio parahaemolyticus in a marine environment. FEMS Microbiol Ecol 73 $159-166$

Yao K, Habibian MT, O'Melia CR (1971) Water and wastewater filtration: concepts and applications. Environ Sci Technol 5:1105-1112

Zimmermann R, Meyer-Reil LA (1974) A new method for fluorescence staining of bacterial populations of membrane filters. Kiel Meeresforsch 30:24-27

Submitted: July 2, 1998; Accepted: June 16, 1999

Proofs received from author(s): November 22, 1999 